Journal of Educational Social Studies
JESS $9(2)(2020): 10-19$
UNNES
http://journal.unnes.ac.id/sju/index.php/jess

\title{
The Social Change of Barru District Society Due to the Construction of the Makassar - Parepare Railway Line
}

\author{
S. Jailany Darwis ${ }^{1 \bowtie}$, Eva Banowati ${ }^{2}$, Fadly Husain ${ }^{2}$ \\ ${ }^{1}$ Universitas Negeri Makassar, Indonesia \\ ${ }^{2}$ Universitas Negeri Semarang, Indonesia
}

\begin{abstract}
Article Info
History Articles

Received:

4 September 2020

Accepted:

2 November 2020

Published:

17 December 2020

Keywords:

Railroad Construction;

Social Changes; Society

Abstract

Indonesia that continued to change over time will no doubt affect the aspects of life. Aspect that could provide sustenance was the need of transportation through the construction of the Makassar - Parepare railway line. The goal was to know the social changes and adaptation patterns of children when social changes occurred as a result of the construction of the Makassar-Parepare railway. This study used qualitative method with descriptive analysis. The informants of the study were; 1) PPK Railway Development of South Sulawesi, 2) Affected communities, 3) Head of BPD in Ajakkang village, and 4) Head of Polewali environment. The data collection technique of this study were interviews, observation, and documentation. The results is construction of the Makassar - Parepare railway led a social change that could be seen based on the process and time. The planned social change occurred because the government is the agent of change in the development. The unplanned social change occurred because of the flooding. The form of social change based on the time of revolution in development has led to conflict due to different interests. The adaptation of children to social changes in society tends to conformity adaptation rather than other forms of adaptation.
\end{abstract}

\footnotetext{
Correspondence address:

Gunungsari Baru Campus, Jl. AP Pettarani, Tidung, Rappocini

Makassar City, Sulawesi Selatan (90222)

p-ISSN 2252-6390

E-mail: sjailanydarwis4@gmail.com
} 


\section{INTRODUCTION}

The globalization era is marked by the depletion of national boundaries politically, economically and culturally. Because the influence of information technology becomes the main trigger to make it easier for humans to get information, even this can happen in remote hemispheres. In addition to the emergence of globalization, the world is already in an era of industrial revolution 4.0 which is marked by digitalization in various aspects of life (Suwardana, 2018), thus demanding all nations around the world to continue to move forward in increasing the capabilities of their human resources. What is happening now is like the speed of a locomotive that cannot be stopped because of the process of changing from traditional to modern (Ariyani \& Nurcahyo, 2014). This phenomenon is something we cannot avoid, but it can be an opportunity to prepare ourselves.

Indonesia, which continues to experience changes from time to time, will certainly affect various aspects of life in society. The mode of transportation can be a supporting element that have functions to provide effective transportation services and is able to reach isolated and remote areas (Sihaloho \& Jinca, 2012). These activities can be improved, if an area is supported by complete and integrated transportation facilities whether on land, sea and air routes.

One of the efforts made by the Government in increasing infrastructure development in the transportation sector is by implementing the National Strategic Project (PSN), which is stated in Presidential Regulation Number 58 of 2017 concerning the Acceleration of Implementation of National Strategic Projects. In general, this program has a long term, PSN can include the construction of airports, ports, dams, toll roads, and so on (Wahyu, 2018). South Sulawesi Province is one of the regions implementing the PSN, by launching the Makassar - Parepare Railway Development Project. PSN is a part of nawacita in completely developing Indonesia. The mode of transportation in the economic sector also has a good impact, so that it can accommodate economic activities ranging from production, distribution and consumption (Hartatik, 2019). This is the government's commitment in building infrastructure equally in order to support increased economic growth and can provide employment.

The construction of the Makassar Parepare Railway Line revived the trains that had existed in Sulawesi in the 19th century, with the Makassar - Takalar route along $47 \mathrm{~km}$, although it only lasted for seven years because it caused losses (Nasrul, et al., 2018). The aim of developing the Makassar - Parepare railway line is to connect areas that have the potential for passenger and freight transport, high speed, with low energy consumption levels (Fitriah, et al., 2018). One of the areas that will be passed by this train line is Kiru-Kiru Village and Ajakkang Village, Soppeng Riaja District, Barru Regency. The construction of this railway line is something new for the local community.

This development gives improvement to various forms of social change. The results of preliminary observations by researchers in the field show that several residents' houses were moved to new places and rice fields had to be converted into railway because they were based on the government's decision as the authority for the Railway Development. In this phenomenon, the government is an agent of change, because it instructs people who have a place to live on land and rice fields where the railroad will be built to leave the area. This observation is also supported by a research from (Marlianawati, et al., 2019) which stated that the development process will make people lose their agricultural land and shelter, and make them to be forced experience the eviction to be used as an airport construction location. Based on this literature review, it confirms that with the development of transportation infrastructure, it has resulted in the conversion of agricultural land and residential land due to the government's decision to determine the railway route, thus it makes the social change. 
The existence of construction and new discoveries in an area will certainly lead to various forms of social change. Social change is a change that occurs in the structure and function of the form of society that is related to thought patterns, social attitudes, norms, values, and various patterns of human behavior in society (Hatu, 2011). Social changes that occur are caused by innovations such as technological developments will change people's behavior. In essence, construction is a process of change that is continuously carried out to get to a better condition in accordance with the norms in society (Miswanto \& Safaat, 2018). The social change that occurs as a result is of course indirectly felt by children as part of the affected community. The adaptation process is not only felt by the community or parents, but the whole process of adaptation to the construction of the railway must also be felt by the affected children.

Social adaptation is a process of change of a person in a social group so that that person can live better in their environment (Sayu, et al., 2013). There are children who are able to adapt by themselves in a new environment, and those who can adapt only when they receive assistance from trusted people such as parents and siblings. This is a common thing that happens to every child, not because of an abnormality but also because of several factors that influence it, including children who are uncomfortable with certain situations or genetic factors where the child has a shy nature.

Robert K. Merton (Wahyuni, 2007; 97) classifies social adaptation patterns into five types:

a. Conformity, is an adaptation pattern in which the individual's attitude follows the ways and goals set by society.

b. Innovation, is an adaptation pattern in which the attitude follows the goals set by society. But he used a method that was prohibited by society.

c. Ritualism, is an adaptation pattern in which an individual behavior has left cultural goals, but still has the principle of sticking to the way agreed upon by the community. d. Retreatism, is an adaptation pattern in which a person's behavior does not follow the desired goals and methods.

e. Rebellion, is an adaptation pattern in which people do not recognize the existing social structure in the community and try to create a new social structure. Existing goals are considered to hinder the goals you want to dream of. Likewise, with existing means of achieving goals that are not recognized.

Researcher interested in raising this problem because the phenomenon of the presence of the Makassar - Parepare railway construction is a new discovery in the world of transportation in South Sulawesi. It can trigger the social change, not only for the local community but for children who have relocated to another place who also feel the same way, so it is interesting to see the patterns of adaptation that occur. So, this will be an element of novelty in this research, considering that research from (Marlianawati et al., 2019) which examines social changes in society due to airport development does not look at the problem of adaptation patterns of the relocated children.

Referring to the background described above, it is necessary to conduct research in the form of social change and adaptation pattern of children to social changes that occur in the community of Soppeng Riaja District, Barru Regency due to the construction of the Makassar - Parepare Railway. This study aimed to determine the form of social change and adaptation patterns of children to social changes that occur in the society of Soppeng Riaja District, Barru Regency due to the construction of the Makassar - Parepare Railway. This research is expected to have implications for the thinking of the people of Soppeng Riaja District that social change will always exist and dynamic in the era of globalization that is increasingly advanced and up to date, various forms of social change have been felt from time to time. So, it needs to be addressed wisely so that social changes that occur can provide great benefits in the future. 


\section{METHODS}

The method used in this research is qualitative. This method is used to describe an in-depth picture of the form of social change and adaptation patterns of children when social change occurs due to the construction of the Makassar - Parepare railway to the people of Soppeng Riaja District, Barru Regency.

This research was conducted in Kiru-Kiru and Ajakkang Villages, Soppeng Riaja District, Barru Regency, South Sulawesi Province. The area of Kiru-Kiru Village has an area of 500 ha and Ajakkang Village 2300 ha. The two areas will be the location for the construction of the 3 $\mathrm{km}$ Makassar - Parepare railway line, while the train station for Soppeng Riaja District will be built in Ajakkang Village.

Data collection techniques in this study were interviews, observation, and documentation. These techniques are mutually sustainable to obtain complete, in-depth and appropriate data in accordance with the research focus. The informants who will be interviewed in this study are: (1) key informants, the PPK Railway Development of South Sulawesi; (2) main informants, the affected community; (3) supporting informants, in this case the Head of BPD Ajakkang Village, and (4) Head of the Polewali Environment.

The data analysis technique used is descriptive analysis technique which aims to identify and analyze data about the form of social change in the Soppeng Riaja District community and children's adaptation patterns when social changes occur due to the construction of the Makassar - Parepare Railway Line.

\section{RESULTS AND DISCUSSION}

Construction in the transportation sector will certainly trigger the social change, as felt by some Soppeng Riaja Subdistrict people who had to give up their homes and rice fields to be relocated for the construction of the Makassar Parepare Railway, which has cost around 2.3 trillion Rupiah.
Social change occurs because of efforts to fulfill needs between individuals and individuals, individuals with groups, or groups with groups, which is a change process carried out by the community itself or due to interactions with outside communities (Mulyadi, 2015). These changes are in accordance with the fundamental nature of humans who are never satisfied with what is obtained, constantly trying to find new things. The community itself has two characteristics, that there is an open nature that can accept the changes that occur, and some are closed, tend to be difficult to accept changes because they are not accustomed to do something they do not understand (Dura, 2016). This kind of phenomenon has become ordinary when there is construction in an area, as in the case with the Soppeng Riaja community.

The findings in Kiru-Kiru and Ajakkang Villages, which become the research locations, found several things that could be studied in relation to the research objectives.

The Forms of Community Social Change Due to the Construction of the Makassar - Parepare Railway Line

The government with all its capabilities is trying to develop in the field of transportation by building adequate public transportation modes such as the construction of the Makassar - Parepare Railway Line in South Sulawesi to achieve efficient transportation modes in terms of energy, time and costs.

Construction in the transportation sector can certainly become a new phenomenon in an area that has not previously been touched by this mode of transportation, causing social changes that are different from the previous situation.

The results of research regarding the forms of social change that occur as a result of the construction of the Makassar - Parepare railway line generally occur because the government realizes that the need of public transportation modes is very needed to support the movement of people who continue to experience movement from one place to another. The construction of the Makassar - 
Parepare Railway line is one of the reasons for the various forms of social change that occur in affected communities, the forms of change that are felt by many of these communities are forms of social change based on processes that are planned or unplanned, and forms of social change based on time that is going fast (revolution).

\section{Forms of Social Change Based on Process}

Social change when viewed based on processes, such as planned changes and unplanned changes occurred in the community phenomenon of Kiru-Kiru Village and Ajakkang Village, Soppeng Riaja District, Barru Regency due to the Construction of the Makassar Parepare Railway. The planned social change occurs as a result of the government acting as the agent of change, initiating the construction of the railway line which is indirectly responsible for all development processes starting from planning to operating the train later.

a. Planned Forms of Social Change

The construction, which began in 2016, involved various stakeholders ranging from the PPK South Sulawesi Railway Development which is under the auspices of the Director General of Railways of the Ministry of Transportation, local governments ranging from provinces to districts / cities, the National Land Agency, State Asset Management Institutions, the High Prosecutor's Office, TNI- The National Police, and the private sector both independent and consortium from within and outside the country.

The role of community leaders who are non-formal leaders also cannot be ignored in this construction, because sometimes what community leaders want can be accepted because of the principle of community obedience (Nasution, 2017). The stakeholders carry out their duties and coordinate during development, such as continuing to socialize with the local community to support these activities. Meanwhile, people who have a residence or paddy field that are affected will be relocated to another place and given compensation.

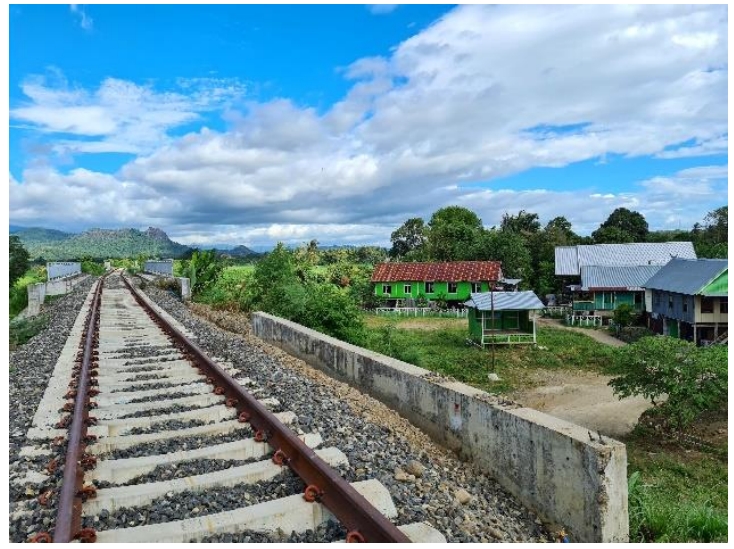

Figure 1. Makassar - Parepare Railway Line in Ajakkang Village

Construction will always change the environmental conditions around the project (Prastiwi, et al., 2016), as in the picture above shows the railroad tracks around residential areas, there are approximately 30 houses that have lived in this area and then moved to another place due to construction. Some of the houses are included in the houses on stilts, so they can still take most of their house materials to move them, without having to build a new house.

This implies that the change in the geographic conditions of the area where the Makassar - Parepare Railway Construction location is a form of planned social change, because the railway construction project is one of the National Strategic Programs (PSN) implemented by the Government as the authority in this development, involving many elements of society.

b. Forms of Unplanned Social Change

Unplanned social changes referred to in the construction of this railway line are changes that can cause harm to the community, for example, there is a large flood which occurs almost every year. After the construction of the railway in Soppeng Subdistrict, it often causes severe flooding if it rains with high intensity, the disaster that does occur every year has an even more severe impact after the existence of the railway line.

Flood disasters have often occurred before the construction of the Makassar - Parepare Railway in Soppeng Riaja Subdistrict if the 
intensity of rainfall increases, but the impact only inundates village roads and several hectares of rice fields. This became a contrast after the railroad was built.

The worst floods ever occurred in 2018, water that was as high as neck at that time caused losses such as damage to residents' houses and village roads. Farmers suffered losses due to floods that submerged hundred hectares of rice fields in Soppeng Riaja District.

The flood event that occurred was caused by the water drain that was made during the construction of the railway line which did not have wide dimensions and was not deep enough. This causes the river in Ajakkang Village to experience sedimentation. So, there will be a reduction in water discharge capacity which causes flooding. The water channels made by railroad workers such as drainage and ditches for residents near the edge of the railroad turned out to be ineffective in overcoming flooding, the water flow from the upstream became spread over the rice fields and residential areas.

The results of the study indicate that the unplanned forms of social change are generally caused by natural conditions. The form of change that is felt by the community is flooding that occurs every year, the flood is caused by a change in the function of rice fields into a railway excavation location so that there is no damning area when it rains. In addition, based on the results obtained by researchers, another form of social change felt by the affected community is a change in local air temperature due to the large number of trees being cut down and replaced by the location of the Makassar Parepare Railway Line Construction.

This form of unplanned social change is in accordance with Soekanto's statement which stated that one of the factors that caused the social change is natural disasters or the physical environment. Changes in the physical environment due to unpredictable natural disasters are sometimes also caused by the actions of the community itself (Soekanto, 2015). The felling of large trees and the conversion of agricultural land which has become one of the water catchment areas must now be changed to the location of the Makassar - Parepare Railway Line Construction. Therefore, the form of social change is not planned in the form of flooding and changes in air temperature, of course it cannot be avoided by the people of Soppeng Riaja District.

2. Forms of Time-Based Social Change

Social change can be seen based on how fast the changes take place. Based on this view, two forms of social change are found, they are changes that take place quickly (revolution) and changes that take place slowly (evolution). The construction of the Makassar - Parepare Railway Line in Soppeng Riaja Subdistrict has triggered changes that encourage people to adapt to developments at a certain time. Of the two forms of social change based on time, when it is related to the construction of the Makassar - Parepare Railway in Soppeng Riaja District, the form of social change that occurs is revolution.

The construction of the Makassar Parepare Railway Line is the government's desire as a form of effort to provide an efficient mode of public transportation for the community in terms of time and cost, to anticipate traffic congestion, especially the Trans Sulawesi route which is feared to be more congested in the future. Of course, this is inseparable from the feasibility study that has been carried out by the government since 2004 from various aspects including social and traffic analysis.

This should be a sign that the government wants a revolution in the transportation sector in the province with the capital city of Makassar, which is indirectly the desire of the people who want to experience public transportation that can run on these tracks.

The revolution that occurs often creates conflicts due to the interests of various parties which are preceded by tensions that are difficult to avoid. As happened during the construction of the railway line in Kiru-Kiru Village. The Kiru-Kiru Public Cemetery (TPU) area which is in danger of being evicted as a result of this construction has led to protests for the community, especially the tomb heirs. The 
polemic arose as a result of the revolution which resulted in the interests of both parties, namely between the government which wanted to immediately carry out the construction of the railroad and the community, in this case the grave heirs who did not want their family graves to be relocated or to have some kind of flyover built.

The construction that takes place with a wide scope is very vulnerable to make various problems that can cause friction and even conflict between the government and the community. Conflicts that occur are caused by various factors, such as disagreeing if construction is present in an area because they are worried about the bad impacts that will result in resistance, the government does not hold a socialization, the unclear price fixing of land compensation, or there are differences in interests. Various infrastructure developments that involve the government as an agent for social change can trigger conflict. Likewise, what happened to the construction of the Makassar - Parepare Railway in Soppeng Riaja District, Barru Regency.

The people of Kiru-Kiru Urban Village do not agree that the Public Cemetery (TPU) should be demolished for rail construction, especially the tomb heirs. In a conflict in social life, people need public space as a forum for direct communication (Piliang, 2012). In the conflict that occurred in Kiru-Kiru Village, the government opened public spaces and made various business efforts by prioritizing a persuasive approach to the community so that the construction would continue to run gradually, such as holding deliberations with tomb heirs.

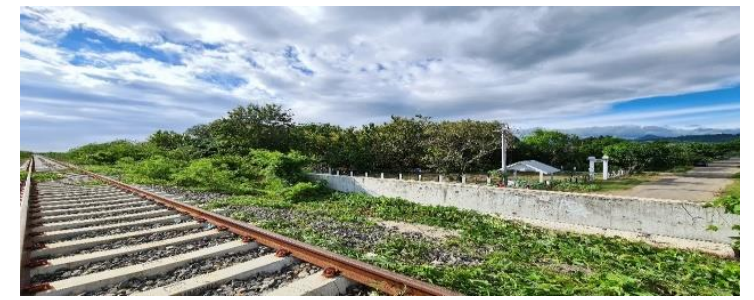

Figure2.Makassar Parepare Railway Line beside the Kiru Kiru Who Had Triggered Conflict Between the Governmentand the Tomb Heirs
The meeting that specifically discussed this problem gave several options, the first was building a cemetery in another place or the second making a railroad flyover line right above the cemetery area. However, this choice was rejected by residents who considered that if they built a new TPU, it would not be possible because there was no available land, while the construction of a railway line must also be carried out immediately. Meanwhile, if you build a railroad over the burial area in the form of a flyover, it is considered unethical and uncivilized if the train operates at the graves of its ancestors.

The meeting did not find solution, so there was a split between the community and the government, the satker, and the workers. The construction of the railroad has been temporarily halted until this problem is resolved. The conflict that lasted for one year made the heirs of the tomb in Kiru-Kiru angry because the government was considered slow in handling this issue, which led to the spotlight of PMII of Barru Branch which led them to hold a demonstration at the Barru Regent's office so that the community's demands were met immediately.

This problem finally came to the attention of stakeholders after coordinating and holding another meeting which was attended by the South Sulawesi Railway Development PPK, Head of the Barru Regency Transportation Service, Head of Barru Regency BPN, Camat Soppeng Riaja, Lurah Kiru-Kiru, Head of the Polewali Environment with grave heirs. The community who had a family at the cemetery requested that the railroad tracks be redesigned so that the TPU was not affected by development, but the proposal was rejected by the South Sulawesi Railway Development PPK on the grounds that if this happened then the railroad tracks that had been designed in such a way would change. , so the budget is getting bigger. If you want to increase the budget, you must propose again, while the proposal is not immediately accepted because it requires a long verification process and raises concerns that the 
construction will slow down further if the demands of the heirs are met.

The polemic finally found a bright spot after the South Sulawesi High Prosecutor's Office intervened to handle this problem after directly inspecting the burial area which has an area of about $1,233 \mathrm{~m} 2$. Monitoring of railway progress is led directly by Kajati Sulsel accompanied by the Regent of Barru and the PPK Railway Development of South Sulawesi.

The results of research that explain the form of social change based on time are revolutionary or in the form of rapid social change. The construction of the Makassar Parepare Railway Line which aims to provide public transportation modes for the community certainly takes a long time, even though the construction process of the railway line takes a long time, the process of social change that occurs in the community is very fast. Because after the plan to build the railway line, inevitably the affected community immediately experienced the form of change quickly, one of the example was the relocation of the house they had occupied so far. The form of revolutionary social change in the affected community has actually created conflicts due to the interests of various parties, preceded by tensions that are difficult to avoid. The tension that arises in society is due to unpreparedness for the social changes that occur that affect the state of mind of the community (Schooler, et al., 2017), especially for brands that are affected and feel disadvantaged.

The form of social change is based on the research results obtained if it is associated with the theory of social change expressed by William F. Ogburn, the cause of the forms of social change that occur in affected communities as a result of the Makassar - Parepare Railway Construction process, which focuses on technological development and the inevitable adjustment process therein (Ogburn, 1964). Technology causes social change quickly and globally, including the development of transportation technology that occurs in the society of Ajakkang Village and Kiru-Kiru Village. The form of change they feel is the result of a new discovery in the form of the development of railway transportation modes which will eventually lead to new patterns of behavior even though there are conflicts that occur in the adjustment process to accept these forms of social change.

\section{The Children's Adaptation Patterns to Social Changes in Society Due to the Construction of the Makassar - Parepare Railway Line}

The existing findings by analyzing descriptively explain that children's adaptation behavior to social changes due to the construction of the Makassar - Parepare Railway tends to conformity adaptation rather than other adaptation patterns such as innovation, ritualism, retreatism, and rebellion adaptation. Children who becomes the research subjects are those aged 7-12 years, where in this phase the children are able to think logically about objects and events that occur in their environment.

The adaptation process must also be carried out by these children, because it is not easy for some of them to accept the various forms of social change that have occurred. The family as the smallest social institution in society carries out various treatments for children so that the adaptation process becomes faster. In the family, a child also learns to socialize, understand, appreciate, and feel all aspects of life that are reflected and become habituation (Agustin, et al., 2015). Therefore, the family is referred as a primary and fundamental institution that can carry out a very strategic function in national development (Soeradi, 2013). This is built with more intense communication between parents and children, or people whom the child trusts more. By taking a persuasive approach with the explanation that they have to move to another place for the good of the people.

Family or parents certainly have the most important role in adapting their child, how he accepts his new environment and lives with his new friends. Starting from a family, everything can develop, such as a children' ability to have an opinion, actualize themselves, and so on (Rustina, 2014). The child's condition in 
accepting any changes that occur will certainly vary depending on how the family's role is in giving an understanding to their child.

Children who are in their new environment after their place of residence has been relocated will experience various benefits, such as access to better schools and meet new friends so that their friendship relationships will be expand.

Forms of conformity adaptation carried out by children who experience social changes as a result of the Makassar - Parepare Railway Construction such as learning and playing both at home and with friends in the surrounding environment, telling stories with parents and siblings, doing learning at school and so on. This was confirmed by his parents in an interview conducted by the researcher, according to his parents, it cannot be separated from the role of the family at home.

In the adaptation pattern of innovation, ritualism, retreatism, children perform various activities such as praying at home, praying before eating, playing mobile games on smartphones, and sometimes quarreling with relatives or friends. Social adaptation behavior is very important for children who experience social changes due to the construction of the Makassar - Parepare Railway Line so that when they do not feel worried anymore when experiencing similar things in the future. Increasing social adaptation attitudes will certainly require cooperation from various parties such as teachers, communities and community leaders.

\section{CONCLUSION}

Based on the phenomena that occur in the people of Soppeng Riaja District, Barru Regency, it can be concluded that the form of social change that occurs as a result of the Makassar - Parepare Railway Construction is a form of social change based on process and time. The form of social change based on the process occurred because it was planned (development was initiated by the government as the agent of change resulting in the process of relocating residents' houses) and unplanned (the occurrence of flood disasters and increased air temperature in Soppeng Riaja District). Meanwhile, the form of social change based on time occurred because of the rapid revolution in development which triggered conflict. The adaptation behavior of children to social changes caused by the Makassar - Parepare Railway Construction tends to conformity adaptation rather than other adaptation patterns such as innovation, ritualism, retreatism, and rebellion adaptation. Social adaptation behavior is very important for children who experience social changes due to the construction of the Makassar - Parepare Railway Line so that when they do not feel worried anymore when experiencing similar things in the future.

\section{REFERENCES}

Agustin, D. S. Y., Suarmini, N. W., \& Prabowo, S. (2015). Peran Keluarga Sangat Penting dalam Pendidikan Mental, Karakter Anak serta Budi Pekerti Anak. Jurnal Sosial Humaniora, 8(1), 46.

Ariyani, N. I., \& Nurcahyo, O. H. (2014). Digitalisasi Pasar Tradisional: Perspektif Teori Perubahan Sosial. Jurnal Analisa Sosiologi, 3(April), 1-12.

Dura, J. (2016). Pengaruh Akuntabilitas Pengelolaan Keuangan Alokasi Dana Desa, Kebijakan Desa, Dan Kelembagaan Desa Terhadap Kesejahteraan Masyarakat. Jurnal Ilmiah Bisnis Dan Ekonomi Asia, 10(2), 26-32.

Fitriah, R., Idrus, M., \& Chairunnisa, A. S. (2018). Analisis Perbandingan Biaya Pengangkutan Peti Kemas Menggunakan Moda Truk, Kereta Api dan Kapal Provinsi Sulawesi Selatan. Jurnal Penelitian Enjiniring, 22(1), 70-75.

Hartatik, E. S. (2019). From Railroad to Highway: Shifting Use of Land Transportation System in the Northern Coast of Central Java. Paramita: Historical Studies Journal, 29(2), 224-234.

Hatu, R. (2011). Perubahan Sosial Kultural Masyarakat Pedesaan (Suatu Tinjauan 
Teoritik-Empirik). Journal Inovasi, 8(4), 111.

Marlianawati, F., Setyowati, D. L., \& Martitah. (2019). Social Change in Farming Community to The Development of West Java Internasional in Sukamulya Village. 8(2), 127-134.

Miswanto, \& Safaat, M. (2018). Dampak Pembangunan Industri Pariwisata terhadap Alih Fungsi Lahan (Studi Tentang Kehidupan Sosial Budaya Masyarakat Desa Teluk Bakau, Kecamatan Gunung Kijang, Kabupaten Bintan, Kepulauan Riau). Jurnal Antropologi: Isu-Isu Sosial Budaya, 20(1), 45-55.

Mulyadi, M. (2015). Perubahan Sosial Masyarakat Agraris ke Masyarakat Industri dalam Pembangunan Masyarakat di Kecamatan Tamalate Kota Makassar. Jurnal Bina Praja, 07(04), 311-321.

Nasrul, F., Najamuddin, \& Asmunandar. (2018). Transportasi Kereta Api Rute Makassar-Takalar (1922-1930). Jurnal Pattingalloang, 5(3), 1-11.

Nasution, R. D. (2017). Kyai Sebagai Agen Perubahan Sosial dan Perdamaian dalam Masyarakat Tradisional. Sosiohumaniora, 19(2), 177-184.

Ogburn, William F. (1964). "On Culture and Social Change" dalam Otis, Dudley, Duncan (Ed.), The Heritage of Sosiology. Chicago: University of Chicago Press.

Piliang, Y. A. (2012). Masyarakat Informasi dan Digital: Teknologi Informasi dan Perubahan Sosial. Jurnal Sosioteknologi, 27(11), 143-156

Prastiwi, E. A., Soesilowati, E., \& Setyowati, D. L. (2016). Strategi Pendekatan Sosial dalam Proses Rencana Pembangunan PLTU Batang. Journal of Educational Social Studies, 1(1), 8-12.

Rustina. (2014). Keluarga dalam Kajian Sosiologi. Musawa, 6(2), 287-322.

Sayu, J. A., Ibrahim, M. Y., \& Budjang, G. (2013). Adaptasi Sosial Siswa Kelas X Pada Boarding School SMA Taruna Bumi Khatulistiwa. Jurnal Pendidikan Dan Pembelajaran Khatulistiwa, 2(9).

Schooler, C., Caplan, L. J., Mounkoro, P. P., \& Diakité, C. (2017). Social Change and Psychological Change in Rural Mali. Journal of Asian and African Studies, 52(7), 965-981.

Sihaloho, A., \& Jinca, M. Y. (2012). Kinerja Transportasi Penyeberangan Trans Maluku Dalam Menunjang Aktivitas Sosial Ekonomi Masyarakat. Warta Penelitian Perhubungan, 24(4), 327-334.

Soekanto, Soerjono. (2015). Sosiologi Sebuah Pengantar. Jakarta: Rajawali Pers.

Soeradi. (2013). Perubahan Sosial dan Ketahanan Keluarga: Meretas Kebijakan Berbasis Kekuatan Lokal. Sosio Informa, 18(02), 83-94.

Suwardana, H. (2018). Revolusi Industri 4.0 Berbasis Revolusi Mental. JATI UNIK: Jurnal Ilmiah Teknik Dan Manajemen Industri, 1(2), 102-110.

Wahyu, M. B. (2018). Pendekatan Manajemen Program dengan Menggunakan Maeutic Machine dalam Percepatan Pencapaian Proyek Strategis Nasional RPJMN 20152019. Jurnal Metris, 19(2018), 65-70.

Wahyuni, Niniek Sri. (2007). Manusia dan Masyarakat. Jakarta: Ganeca Exact. 